\title{
ADAPTASI ARSITEKTUR TRADISIONAL BALI PADA TEMPAT-TEMPAT KOMUNAL DI DESA BALINURAGA, KALIANDA, LAMPUNG SELATAN
}

\author{
Monika Ata ${ }^{1}$, Agus S. Ekomadyo ${ }^{2}$ \\ Program Studi Magister Arsitektur SAPPK Institut Teknologi Bandung \\ Jl. B, Lb. Siliwangi, Kecamatan Coblong, Kota Bandung \\ *Email: ${ }^{1}$ monikaata@gmail.com
}

\begin{abstract}
ABSTRAK
Kebudayaan tercipta dari perilaku dan pandangan hidup suatu tatanan masyarakat dengan latar belakang tertentu. Perilaku pemukim pada suatu permukiman menghasilkan keberagaman dan pola yang unik sehingga melahirkan identitas pada kebudayaannya sendiri dan pada wilayah tertentu. Adapun proses yang dihasilkan dari kemampuan manusia untuk menyesuaikan diri dengan lingkungannya demi bertahan hidup serta adanya perubahan pola dan pandangan hidup manusia disebut adaptasi. Adaptasi tentu dilakukan oleh setiap suku pendatang di daerah perantauannya. Proses adaptasi memiliki konsep Adaptation (adaptasi), Goals (tujuan), Integration (integrasi), dan Lattern Pattern Maintenance (pemeliharaan pola-pola) sesuai dengan teori yang disebutkan oleh Partson. Adapun salah satu kasus dari terjadinya proses adaptasi terjadi pada masyarakat suku Bali etnis Nusa Penida yang merantau ke tanah Lampung, Sumatra sejak tahun 1950an memiliki kemampuan beradaptasi yang baik dengan bukti mereka dapat bertahan hidup dengan menghasilkan kondisi sosial dan ekonominya yang cukup baik. Pada penelitian ini, fokus penelitian pada adaptasi arsitektur tradisional Bali yang menganut asta kosala-kosali pada tempat-tempat komunal di desa Balinuraga, Kalianda, Lampung Selatan. Tempat komunal pada asta kosala-kosali terdapat sedikitnya 6 tipe tempat-tempat komunal dengan beberapa tingkatan, yakni tingkat satu kepala keluarga, keluarga satu marga (pemaksan), banjar (dusun), dan tingkat desa. Penelitian ini menggunakan metode analisis kualitatif yang akan dilaksanakan dengan membandingkan data sekunder mengenai tempat-tempat komunal pada permukiman tradisional masyarakat Bali di Bali dan data hasil dari observasi serta wawancara dengan warga di desa Balinuraga, Kalianda, Lampung Selatan. Ditemukan perbedaan berupa penggunaan fungsi dari tempat-tempat komunal serta ketiadaan bale banjar pada tingkat desa. Ditemukan faktor-faktor yang mempengaruhi proses adaptasi adalah ekonomi, perubahan ekologis, politik, kebudayaan, dan sosialisasi.
\end{abstract}

Kata Kunci: Adaptasi, Arsitektur Tradisional Bali, Permukiman Tradisional, Etnis Nusa Penida, AGIL.

\section{PENDAHULUAN}

Kebudayaan pada tata pola ruang dan pola permukiman tercipta dari perilaku dan pandangan hidup suatu tatanan masyarakat dengan latar belakang tertentu. Terdapat beberapa perilaku pemukim yang unik dan pandangan hidup yang beraneka ragam antar permukiman yang berbeda menghasilkan pola lingkungan binaan yang berbeda pula. Hal ini yang kemudian lahir menjadi identitas dari kebudayaan suatu tempat atau wilayah.

Suatu proses yang dihasilkan dari kemampuan manusia untuk menyesuaikan diri terhadap lingkungannya demi bertahan hidup disebut proses adaptasi. Sebagai contoh lahirnya cara-cara dan perubahan pandangan hidup yang dihasilkan oleh perantau/pendatang untuk memperoleh keseimbangan yang tepat dengan latar belakang perantau dan lingkungan yang ia tinggali (Pelly, 1998).

Masyarakat suku Bali sejak dulu memiliki hal-hal yang tetap melekat pada setiap sendi kehidupan mereka, yakni agama, adat istiadat, kepercayaan dan sistem peribadatan mereka sebagai landasan-landasan dalam segala aspek kehidupan masyarakat suku Bali (Dwijendra, 2008). Suku Bali yang memiliki latar belakang sejarah agama Hindu menyebabkan tatanan kehidupan pribadi maupun sosial mereka sangat 
melekat pada agama Hindu. Norma-norma, tradisi serta nilai-nilai kehidupan yang tercipta menjadi bukti bahwa agama Hindu merupakan dasar aturan kehidupan mereka sehari-hari. Fakta-fakta inilah yang membedakan masyarakat suku Bali dari suku lainnya.

Pada tahun 1952 pemerintah Indonesia memprakarsai kebijakkan transmigrasi guna menghindari kepadatan penduduk di kota-kota besar, meratakan jumlah penduduk dan pembangunan di Indonesia. Transmigrasi dari pulau Jawa serta Bali disebar ke beberapa pulau di Indonesia seperti Kalimantan, Sumatera, Sulawesi dan Sumbawa. Lampung menjadi salah satu tujuan utama para transmigran, hal ini dibuktikan transmigrasi pertama dari pulau Jawa pada tahun 1938 bertempat di Gedong Tataan, Pesawaran, Provinsi Lampung. Beberapa daerah di Provinsi Lampung yang menjadi tujuan transmigrasi suku Bali adalah Seputih Rahman, Lampung Tengah yang datang dari pulau Bali, disusul oleh transmigran suku Bali yang mendatangi Dusun Napal, Sidomulyo serta Desa Balinuraga, Kalianda, Kabupaten Lampung Selatan yang datang dari pulau Nusa Penida.

Suku Bali etnis Nusa Penida yang sudah bertempat tinggal dan resmi menjadi penduduk Kalianda, Lampung Selatan selama beberapa dekade ini masih memegang teguh aturan-aturan dari tanah leluhur mereka. Namun, adanya perbedaan lingkungan dan kebudayaan serta perbedaan kondisi alam mempengaruhi aturanaturan tersebut seperti pola tata ruang spasial, tipo-morfologi bangunan permukiman, sosiokultural wilayah dan lain sebagainya terkait dengan efektifitas dan fleksibiltas dalam rangka adaptasi terhadap lingkungan geografi, sistem struktur sosial, pengetahuan baru, perubahan kependudukan dan profesi masyarakat Provinsi Lampung. Proses perubahan sebelumnya yang kita sebut dengan adaptasi tentu terjadi pada berbagai aspek dalam kehidupan suatu permukiman yang dihuni oleh suku pendatang.

Desa Balinuraga terdiri dari 7 Dusun di mana 5 di antaranya merupakan permukiman suku Bali etnis Nusa Penida. Secara arsitektural, permukiman dengan tradisi dan kebudayaan Bali sangat mudah dikenali dari perbedaan tata ruang spasial dengan keberadaan rumah peribadatan pribadi, rumah peribadatan milik Banjar, serta ruang-ruang komunal yang merupakan ciri khas dari kebudayaan suku Bali sekaligus menjadi sasaran pada penelitian ini berikut dengan faktor-faktor internal dan eksternal yang mempengaruhi proses adaptasi tersebut.

Dengan ditemukannya hasil dan dampak dari adaptasi sebagai hasil dari penelitian ini, kita dapat menghasilkan kesimpulan berupa tindakan apa yang sebaiknya diambil sebagai langkah untuk memperbaiki keadaan tempattempat komunal pada permukiman suku Bali etnis Nusa Penida di Desa Balinuraga, Kalianda, Lampung Selatan guna menaikkan kualitas permukiman.

\section{METODE PENELITIAN}

Penelitian ini dilaksanakan dengan cara pengumpulan data sekunder serta data hasil dari observasi berupa wawancara dengan warga etnis Nusa Penida yang bermukim di salah satu desa Balinurage, Kalianda, Lampung Selatan yang dijadikan sampel penelitian. Kemudian data yang telah terkumpul tersebut akan dibandingkan antara data sekunder dan data hasil observasi dengan metode analisis kualitatif. Hasil dari perbandingan tersebut dakan dipresentasikan dalam bentuk tabel agar hasil adaptasi yang terjadi dapat lebih mudah dilihat lalu akan dideskripsikan setelahnya. Dari hasil deskripsi yang akan dibahas, akan dibuktikan bahwa ada atau tidak adanya adaptasi yang terjadi pada dusun yang dijadikan sampel di Desa Balinuraga, Kalianda, Lampung Selatan.

\section{PEMBAHASAN}

\section{Adaptasi Budaya sebagai Hasil dari Respon Interaksi Sosial}

Adaptasi merupakan bentuk dari perangai sosial yang muncul akibat kesadaran akan kebutuhan, tujuan hidup serta hasrat personal. Pola sosiokultural baru dihasilkan dari proses adaptasi yang dilakukan secara sengaja dan tidak dengan proses acak maka dari itu evolusi sosiokultural terjadi secara cepat (Sanderson, 2003).

Menurut Parson (1975), adanya urbanisasi dan pertumbuhan ekonomi yang berlangsung cepat memberikan perubahan pada unsur-unsur kebudayaan yang juga disebabkan oleh adanya gerakan sosial sehingga diperlukan adanya adaptasi budaya sebagai respon dari interaksi yang terjadi serta terciptanya sebuah lingkungan sosial. 
Proses adaptasi budaya dilakukan untuk mencapai keseimbangan yang dihasilkan dari peran masing-masing individu dalam masyarakat. Keseimbangan dapat dapat dicapai dengan konsep Adaptation (adaptasi), Goals (tujuan), Integration (integrasi), dan Latent Pattern Maintenance (pemeliharaan pola-pola). Adaptasi merupakan proses yang dilaksanakan oleh individu, integrasi adalah bagaimana masyarakat terhubung satu sama lain, tujuan merupakan hal yang ingin dicapai oleh suatu masyarakat atas norma-norma yang telah ada dan pemeliharaan pola-pola adalah kondisi di mana masyarakat memiliki peluang untuk menjaga tatanan sistem yang terbentuk (Parsons, 1975).

Konsep AGIL di atas digunakan dalam sebuah struktur fungsionalisme yang merupakan sudut pandang untuk menafsirkan masyarakat sebagai sebuah struktur yang saling berhubungan di mana di dalamnya terdapat subsistem ekonomi, perubahan ekologis, politik, kebudayaan dan sosialisasi (Talcott Parsons, 1961). Di dalam struktur fungsionalisme terhadap beberapa unsur, yakni sistem norma yang memaparkan mengenai kerjasama antar individu dalam masyarakat, organisasi ekonomi, alat-alat pendidikan dan organisasi politik yang mengatur kebijakkan dalam masyarakat.

Maka dari itu, adaptasi merupakan proses di mana sistem dan norma dalam suatu budaya terhubung dengan lingkungan barunya (Kaplan, 2000).

\section{Konsep Pembentuk Ruang Masyarakat Bali}

Desa tradisional Bali selalu berpegang pada konsep yang menyelaraskan bhuana agung (alam semesta) dan bhuana alit (manusia). Dalam kasus ini yang dimaksudkan sebagai bhuana agung adalah lingkungan binaan sedangkan bhuana alit adalah manusia yang membina dan menempati lingkungan tersebut (Soebandi, 1990). Kedua konsep makro dan mikrokosmos ini berdasarkan agama Hindu yang mengajarkan manusia untuk hidup secara harmonis dan selalu menjaga keseimbangan kosmos dan segala isinya.

Tri Hita Karana yang merupakan salah satu karya dari karya-karya Empu Kuturan dalam aspek kebudayaan yang memiliki makna tiga unsur utuh penyebab kebaikan yang terdiri dari atma (roh/jiwa), prana (tenaga), angga (jasad/fisik). Tri Hita Karana diterapkan dalam konsep pola ruang dan pola perumahan pada desa tradisional Bali.

Pada konsep orientasi lingkungan binaan, Tri Angga memiliki tata nilai Hulu Teben yang dibuat demi menciptakan keselarasan antara bhuana agung dan bhuana alit. Hulu Teben terdiri dari tiga konsep orientasi, orientasi sumbu ritual Kangin (matahari terbit) - Kauh (matahari terbenam), orientasi dengan konsep sumbu bumi/natural Kaja (arah gunung) - Kelod (arah laut) dan orientasi dengan konsep Akasa (alam atas) - Pertiwi (alam bawah).

Penggabungan antara konsep orientasi sumbu bumi (Kaja-Kelod) dan orientasi sumbu ritual (Kangin-Kauh) menghasilkan konsep turunan selanjutnya, yaitu Sanga Mandala yang selanjutnya menjadi konsep tata ruang dalam lingkungan binaan. Sanga Mandala terlahir dari sembilan manifestasi Tuhan, yakni Dewata Nawa Sanga dengan satu Tuhan di tengah sebagai penyeimbang alam semesta dan delapan lainnya menyebar ke delapan penjuru arah mata angin. Konsep Sanga Mandala yang bertujuan untuk keseimbangan alam semesta ini menjadi dasar pembagian area kegiatan bhuana alit dalam pola tata spasial bangunan yang juga menggunakan konsep tersebut (Gambar 1).

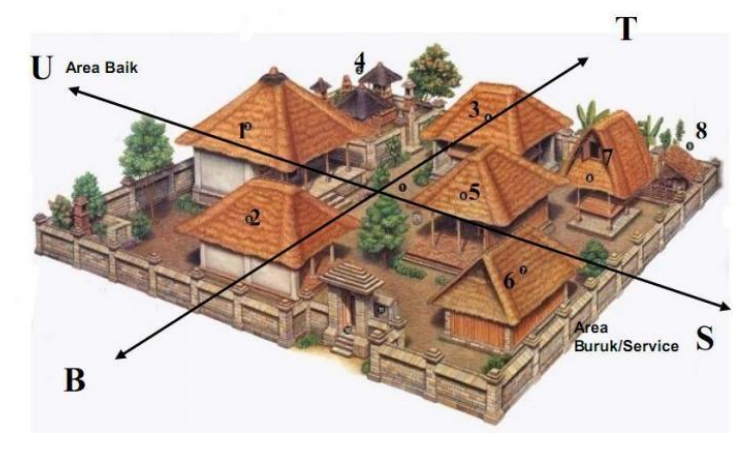

Gambar 1. Tatanan Rumah Tradisional Bali Tingkat Satu KK dan Pemaksan

Sumber: inputbali.com/budaya-bali/asta-kosalakosali-fengshui-tata-ruang-bangunan-bali

1. Rumah utama

2. Bale Bengong

3. Bale Banjar

4. Pura

5. Bale Pemaksan

6. Servis

7. Gudang

8. Bale Kulkul

Konsep asta kosala-kosali diterapkan pada tatanan lingkungan binaan permukiman tradisional Bali, begitu juga pada pengadaan tempat-tempat komunal di permukiman tersebut. 


\section{Tempat-tempat Komunal \\ Permukiman Tradisional Bali}

Kehidupan masyarakat suku Bali dalam ikatan-ikatan keluarga, banjar dan desa yang masing-masing memiliki autoritas administratifnya masing-masing pula. Jabatanjabatan dalam bidang administrasi ini dipegang oleh kasta Ksatria yang menjadi pokok pemikir dalam organisasi tingkat banjar sampai tingkat desa. Sedangkan kelompok organisasi profesional disebut Sekha dan dibagi sesuai dengan bidang pekerjaannya, Sekha Manyi, Sekha Jaring, Sekha Tari, dst.

Kebutuhan akan ruang sebagai sarana untuk melakukan kegiatan bersama sesuai dengan tingkat ikatannya masing-masing, menciptakan ruang-ruang komunal pada permukiman tradisional Bali. Masing-masing ruang komunal memiliki fungsi dan tujuannya sendiri disesuaikan dengan tingkat kebutuhan, sasaran pengguna serta kemampuan ekonomi dari pemilik (Tabel 1).

$\underline{\text { Tabel 1. Tempat-tempat Komunal Permukiman Tradisional Bali Berdasarkan Asta Kosala-kosali }}$

\begin{tabular}{|c|c|c|c|c|c|c|}
\hline Nama & Fungsi & Pengguna & $\begin{array}{c}\text { Jumlah } \\
\text { Tiang }\end{array}$ & $\begin{array}{c}\text { Konstruksi \& } \\
\text { Material }\end{array}$ & Bukaan & Orientasi \\
\hline \multirow{3}{*}{ Bale Banjar } & Musyawarah & $\begin{array}{l}\text { Sebagian atau seluruh } \\
\text { masyarakat banjar/KK }\end{array}$ & $\begin{array}{l}4,6,8, \\
10,12 \\
\text { dst. }\end{array}$ & $\begin{array}{l}\text { Atap limasan } \\
\text { berpuncak satu }\end{array}$ & $\begin{array}{l}\text { Tanpa } \\
\text { dinding }\end{array}$ & \\
\hline & Kegiatan adat agama & & & & $\begin{array}{l}\text { Dapat } \\
\text { diperluas }\end{array}$ & $\begin{array}{l}\text { Arah } \\
\text { gunung }\end{array}$ \\
\hline & Kegiatan sosial & & & & & \\
\hline \multirow{3}{*}{ Bale Pemaksan } & $\begin{array}{l}\text { Musyawarah } \\
\text { (menjelang upacara } \\
\text { odalan/pujawali) }\end{array}$ & $\begin{array}{l}\text { Ikatan keluarga } \\
\text { (pemaksan) }\end{array}$ & $4,6,8$ & $\begin{array}{l}\text { Atap limasan } \\
\text { berpuncak satu }\end{array}$ & $\begin{array}{l}\text { Tanpa } \\
\text { dinding }\end{array}$ & $\begin{array}{l}\text { Arah } \\
\text { gunung }\end{array}$ \\
\hline & $\begin{array}{l}\text { Rapat anggota/warga } \\
\text { pemaksan }\end{array}$ & Organisasi seprofesi & & & $\begin{array}{l}\text { Dapat } \\
\text { diperluas }\end{array}$ & \\
\hline & $\begin{array}{l}\text { Rapat kelompok } \\
\text { kerja }\end{array}$ & & & & & \\
\hline \multirow{7}{*}{ Wantilan } & Sementara & $\begin{array}{l}\text { Sebagian atau seluruh } \\
\text { masyarakat banjar/KK }\end{array}$ & 12 & Atap bertingkat & $\begin{array}{l}\text { Tanpa } \\
\text { dinding }\end{array}$ & \\
\hline & Musyawarah & Anggota pemaksan & & (metumpang) & $\begin{array}{l}\text { Dapat } \\
\text { diperluas }\end{array}$ & \\
\hline & Rapat anggota & Organisasi seprofesi & & Rangka bambu & & \\
\hline & Tempat pertunjukkan & & & & & $\begin{array}{l}\text { Arah } \\
\text { gunung }\end{array}$ \\
\hline & Tempat olahraga & & & & & \\
\hline & Tempat pendidikan & & & & & \\
\hline & Kepariwisataan & & & & & \\
\hline \multirow{5}{*}{ Bale Agung } & Serba guna: & Warga desa & 12 & $\begin{array}{l}\text { Atap limasan } \\
\text { berpuncak satu }\end{array}$ & $\begin{array}{l}\text { Tanpa } \\
\text { dinding }\end{array}$ & \\
\hline & Musyawarah & & & & $\begin{array}{l}\text { Dapat } \\
\text { diperluas }\end{array}$ & $\begin{array}{l}\text { Arah } \\
\text { gunung }\end{array}$ \\
\hline & Persiapan upacara & & & & & \\
\hline & Pelaksanaan upacara & & & & & \\
\hline & Kegiatan adat lainnya & & & & & \\
\hline \multirow{4}{*}{ Bale Sumanggen } & $\begin{array}{l}\text { Serba guna: } \\
\text { Musyawarah }\end{array}$ & Warga desa atau KK & 8 & $\begin{array}{l}\text { Atap sementara } \\
\text { (tetaring) }\end{array}$ & $\begin{array}{l}\text { Tanpa } \\
\text { dinding } \\
\text { Dapat } \\
\text { diperluas }\end{array}$ & $\begin{array}{l}\text { Arah } \\
\text { gunung }\end{array}$ \\
\hline & Persiapan upacara & & & $\begin{array}{l}\text { Tanpa balai- } \\
\text { balai }\end{array}$ & & \\
\hline & Pelaksanaan upacara & & & & & \\
\hline & Kegiatan adat lainnya & & & & & \\
\hline
\end{tabular}


Tabel 1. (Lanjutan)

\begin{tabular}{|c|c|c|c|c|c|c|}
\hline Nama & Fungsi & Pengguna & $\begin{array}{l}\text { Jumlah } \\
\text { Tiang }\end{array}$ & $\begin{array}{c}\text { Konstruksi \& } \\
\text { Material }\end{array}$ & Bukaan & Orientasi \\
\hline Bale kulkul & $\begin{array}{l}\text { Memanggil anggota } \\
\text { banjar untuk datang } \\
\text { ke Banjar/tempat- } \\
\text { tempat yang } \\
\text { ditentukan dengan } \\
\text { menggunakan } \\
\text { kentongan }(\mathrm{kulkul})\end{array}$ & $\begin{array}{l}\text { Anggota banjar atau } \\
\text { anggota pemaksan }\end{array}$ & 4 & Menara beratap & Menara & $\begin{array}{l}\text { Arah } \\
\text { gunung }\end{array}$ \\
\hline Bale Bengong & $\begin{array}{l}\text { Musyawarah (duduk- } \\
\text { duduk di lantai) }\end{array}$ & Anggota banjar & $\begin{array}{l}4,6,8 \\
10,12\end{array}$ & $\begin{array}{l}\text { Atap limasan } \\
\text { berpuncak satu }\end{array}$ & $\begin{array}{l}\text { Terbuka } \\
\text { keempat } \\
\text { arah }\end{array}$ & $\begin{array}{l}\text { Arah } \\
\text { gunung }\end{array}$ \\
\hline $\begin{array}{l}\text { Bale } \\
\text { Mandapa/Pendopo }\end{array}$ & Upacara adat & Anggota banjar & 12 & $\begin{array}{l}\text { Atap limasan } \\
\text { berpuncak satu }\end{array}$ & $\begin{array}{l}\text { Terbuka } \\
\text { keempat } \\
\text { arah }\end{array}$ & $\begin{array}{l}\text { Arah } \\
\text { gunung }\end{array}$ \\
\hline Natah/Pekarangan & Serba guna & Satu KK & - & - & $\begin{array}{l}\text { Biasanya } \\
\text { didirikan } \\
\text { tenda non- } \\
\text { permanen }\end{array}$ & \\
\hline
\end{tabular}

\section{Latar Belakang Kebudayaan Suku Bali Etnis Nusa Penida di Lampung}

Nusa Penida adalah sebuah pulau yang terdiri dari gugusan Nusa. Pulau Nusa Penida merupakan pulau yang ditinjau dari keadaan alam dan geografisnya merupakan pulau yang tidak memiliki kekayaan alam dan cenderung mengalami paceklik selama musim kemarau karena tanah yang kering dan terdiri dari batubatu karang serta batu kapur. Dengan demikian, pulau Nusa Penida pada masa perjanjian tujuh kerajaan di Bali pada 1854M digunakan sebagai pulau pembuangan yang diharapkan oleh pangadilan pada masa itu agar masyarakat yang dipindahkan ke lokasi tersebut dapat melakukan interospeksi sekaligus dapat membuka potensi hasil bumi di pulau tersebut.

Pada tahun 1952, pemerintah dengan kebijakkan transmigrasinya membuka jalan hidup baru bagi suku Bali di Nusa Penida ini. Masyarakat etnis Nusa Penida ini bertransmigrasi menuju pulau-pulau yang dijadikan target sasaran transmigrasi. Untuk provinsi Lampung sendiri, etnis Nusa Penida menempati wilayah Lampung Selatan tepatnya di Desa Sidomulyo dan Desa Balinuraga, Kabupaten Kalianda.

Masyarakat suku Bali yang bertempat tinggal di Lampung Selatan membuka ladangladang pertanian baru pada wilayah yang disediakan dengan merombak hutan-hutan di sekitar lokasi transmigrasi mereka. Bertani dan berladang merupakan mata pencaharian awal mereka sebagai pendatang di pulau Sumatra. Seiring dengan berjalannya waktu, masyarakat di Balinuraga memiliki profesi lain di luar bertani untuk bertahan hidup di tanah perantauan. Profesi seniman, pedagang, guru, dsb. ditekuni bersamaan dengan ladang yang terus mereka olah. Keuletan etnis Nusa Penida ini dapat kita lihat dari keadaan desa mereka yang cukup maju ditinjau dari segi ekonomi dan sosial.

Sistem kemasyarakatan di Desa Balinuraga masih menggunakan sistem dan tata aturan dari suku Bali asalnya dengan adanya lembaga Legislatif, Eksekutif dan Yudikatif. Lembaga Legislatif dipegang oleh masyarakat, lembaga Eksekutif dipegang oleh kasta Ksatria sebagai pemimpin dalam kegiatan musyawarah warga desa, sedangkan lembaga Yudikatif dipegang oleh kekuasaan tertinggi, yakni arwah para leluhur.

Dalam pelaksanaan peribadatannya, suku Bali di desa Balinuraga masih memegang tata aturan dari masa kerajaan Majapahit, yaitu kepercayaan agama Hindu. Mereka memiliki Pura kecil untuk lingkup satu pekarangan, Pura untuk lingkup satu marga, serta Pura untuk lingkup satu banjar. Pelaksanaan kegiatan ibadah dipimpin oleh kasta Brahmana di mana kasta Brahmana memiliki kekhususan berupa ruangan tempat untuk berdiam diri di dekat wilayah pura. Masyarakat juga masih memegang aturan penghormatan terhadap pendahulu mereka, seperti perletakkan kuburan di dekat lokasi Pura dan pendirian Pura-Pura kecil sebagai tempat sembahyang kepada para leluhur (Gambar 2). 


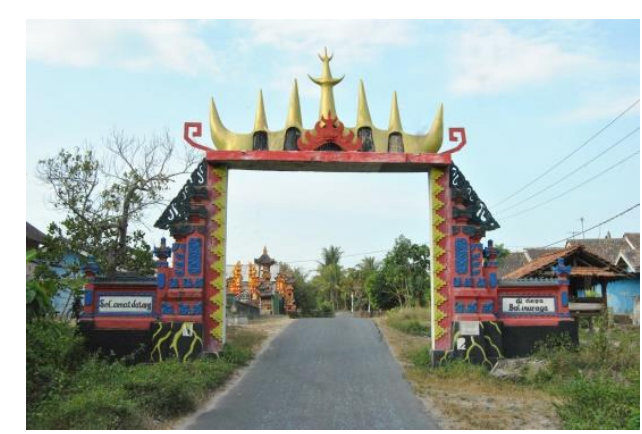

Gambar 2. Gerbang Menuju Desa Bali Nuraga Sumber: Monika Ata, 2015

\section{Tempat-tempat Komunal di Desa Balinuraga dan Strategi Adaptasi \\ Ruang komunal atau banjar pada rumah} suku Bali terdiri dari beberapa jenis tergantung dengan kemampuan ekonomi keluarga dan tingkat kebutuhan akan ruang komunal tersebut. Tingkat satu kepala keluarga di sini ditandai oleh pekarangan (natah). Ketika satu keluarga sudah memiliki pekarangannya sendiri yang terpisah dengan rumah induk atau rumah utama, mereka wajib membuat tempat sembahyang dan ruang kebutuhan lainnya sendiri.

Pekarangan atau natah merupakan salah satu jenis ruang komunal dalam permukiman masyarakat suku bali. Pola natah mengikuti konsep orientasi Akasa-Pertiwi dengan adanya satu titik pusat sebagai ruang kegiatan bersama dan fasilitas publik.

Natah yang letaknya madya pada pola rumah bersifat fleksibel. Ketika keluarga memiliki acara atau keperluan, mereka memasang tenda atau penutup atas pada natah sehingga terbentuklah ruang untuk berkegiatan bersama. Seperti acara ritual keagamaan maupun membuat acara kesenian.

Adapun jenis selanjutnya adalah sakepat yang merupakan ruang terbuka dengan jumlah tiang empat. Nama sakepat sendiri berasal dari sake (soko/penyokong) dan empat (jumlah tiang empat) yang berarti empat penyokong. Sakepat yang saya temukan sangat sederhana, hanya berukuran $2 \mathrm{~m} \times 2 \mathrm{~m}$ dengan atap konstruksi limasan (kampiah). Bale sakepat ditemukan pada natah tingkat satu kepala keluarga dan keluarga satu marga (Gambar 3).

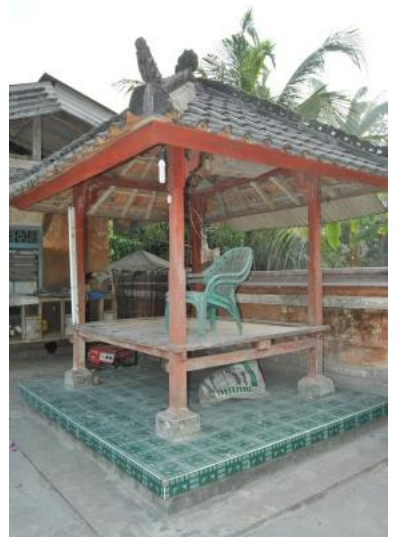

Gambar 3. Bale Sakepat Pada Natah Keluarga Satu Marga

Sumber: Monika Ata, 2015

Satu lagi bale yang memiliki tipologi serupa dengan sakepat adalah sakenam. Sakenam (enam penyokong) sendiri sangat sedikit ditemukan karena lebih menampung banyak orang dengan luas sekitar $2 \mathrm{~m}$ x $6 \mathrm{~m}$ sehingga lebih diperuntukkan bagi natah keluarga satu marga. Sakenam yang ditemukan di desa Balinuraga ini memiliki fungsi sebagai bale bengong di mana aktivitas bersantai yang lumrahnya dilakukan pada sore hari maupun aktifitas membuat kerajinan yang dilakukan secara bersama-sama ketika akan diadakannya pentas seni. Dengan adanya bale sakenam pada natah keluarga satu marga, bale sakepat yang tersedia menjadi tidak berfungsi secara maksimal karena sakenam dan natah yang tersedia sudah memiliki daya tampung yang lebih besar (Gambar 4).

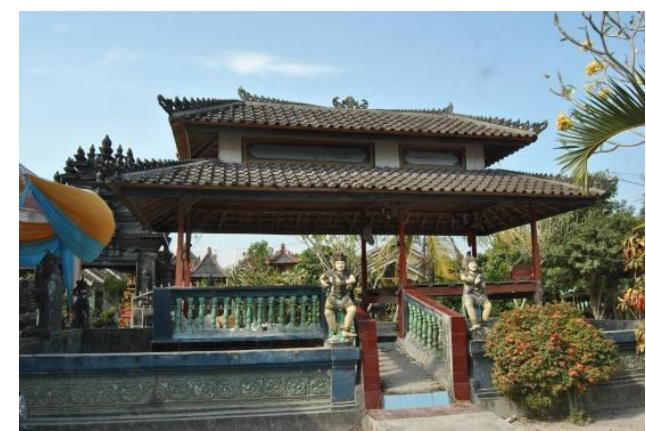

Gambar 4. Bale Bengong pada Natah Tingkat Keluarga Satu Marga Sumber: Monika Ata, 2015

Jenis ruang komunal lainnya yang terdapat pada natah keluarga satu marga dan pada tingkat banjar adalah bale banjar. Bale banjar merupakan ruang komunal dengan 
jumlah tiang 4, 8, 10, 12 dst. dan memiliki atap limasan berpuncak satu.

Bale banjar yang saya temukan pada rumah keluarga seniman memiliki tiang sejumlah 8 tiang dengan perbedaan ketinggian pada lantai yang berfungsi sebagai tempat untuk duduk para petinggi ketika akan mengadakan musyawarah dan juga penaikkan lantai sekitar $40 \mathrm{~cm}$ yang digunakan sebagai panggung pertunjukkan kesenian. Dengan adanya panggung yang disediakan pada bale banjar ini, maka bale banjar juga memiliki fungsi sebagai wantilan. Bale banjar dilengkapi dengan gudang tempat penyimpanan alat-alat kesenian dan keperluan lainnya (Gambar 5).

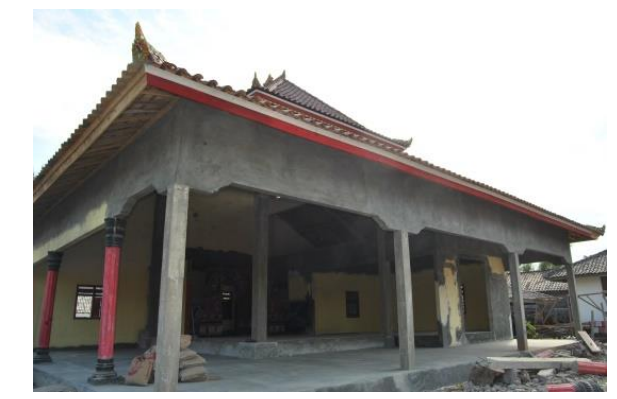

Gambar 5. Bale Banjar/Wantilan pada Natah Keluarga Satu Marga

Sumber: Monika Ata, 2015

Bale banjar pada tingkat dusun (banjar) memiliki jumlah tiang sebanyak 12 tiang dengan ukuran yang jauh lebih luas dan memiliki atap limasan. Untuk perbedaan ketinggian antar lantai masih sama dengan bale banjar yang terletak di rumah keluarga satu marga dengan ketinggian lantai terendah adalah $50 \mathrm{~cm}$ dari tanah. Bale banjar ini juga memiliki panggung sebagai tempat pertunjukkan kesenian. Dilengkapi dengan gudang penyimpanan dan sumur. Natah yang berada di bale banjar tingkat banjar ini cukup luas (Gambar 6, dan 7).

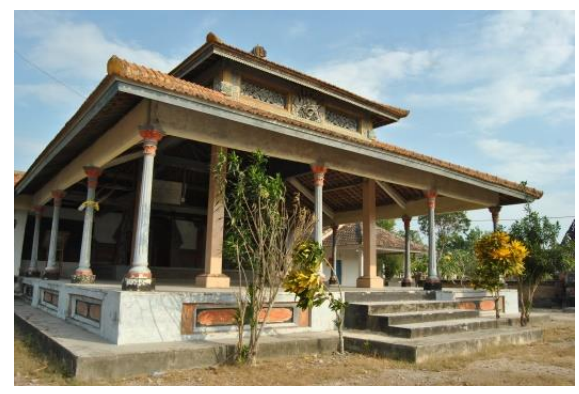

Gambar 6. Bale Banjar/Wantilan Tingkat Satu Banjar

Sumber: Monika Ata, 2015

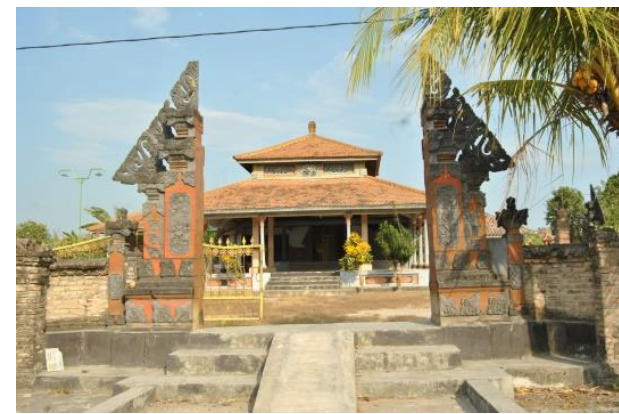

Gambar 7. Gerbang Masuk Bale Banjar Tingkat Banjar

Sumber: Monika Ata, 2015.

Bale kulkul merupakan bale yang berbentuk menara dilengkapi dengan kentongan (kulkul) yang berfungsi untuk memanggil warga dan ditemukan pada rumah keluarga tingkat satu marga terletak bersebelahan dengan bale banjar maupun pada natah bale banjar tingkat banjar (Gambar 8).

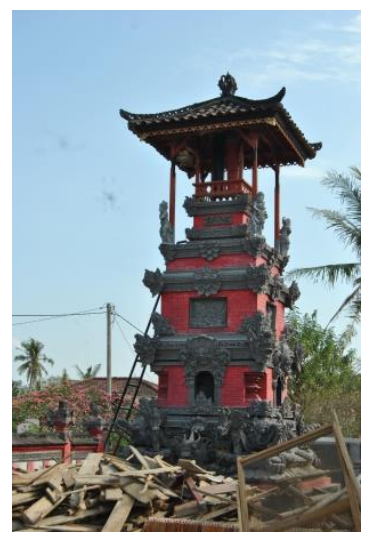

Gambar 8. Bale Kulkul pada Natah Rumah Keluarga Satu Marga Sumber: Monika Ata, 2015

Ruang komunal pada tingkat desa tidak tersedia. Ketika akan dilaksanakan kegiatan bagi 5 (lima) warga dusun dari 7 (tujuh) dusun pada desa Balinuraga, mereka menggunakan ruang komunal pada dusun yang menyelenggarakan acara tersebut (Tabel 1, dan 2).

Tabel 2. Tempat-tempat Komunal yang Terdapat di Desa Balinuraga 


\begin{tabular}{cccc}
\hline Tempat komunal & Tingkat & $\begin{array}{c}\text { Ketersediaan } \\
\text { pada sampel }\end{array}$ & Orientasi \\
\hline Natah/Pekarangan & $1 \mathrm{KK}$ & Ada & Barat \\
Bale Sakepat & $1 \mathrm{KK}$ & Ada & Barat \\
Natah/Pekarangan & 1 Pemaksan & Ada & Barat \\
Bale Sakepat & 1 Pemaksan & Ada & Barat \\
Bale Bengong & 1 Pemaksan & Ada & Barat \\
Bale Kulkul & 1 Pemaksan & Ada & Barat \\
Bale Banjar/Wantilan & 1 Pemaksan & Ada & Barat \\
Natah/Pekarangan & 1 Banjar & Ada & Barat \\
Bale Kulkul & 1 Banjar & Ada & Barat \\
Bale Banjar/Wantilan & 1 Banjar & Ada & Barat \\
Bale Kulkul & 1 Desa & Tidak Ada & Barat \\
Bale Banjar/Wantilan & 1 Desa & Tidak Ada & Barat \\
\hline
\end{tabular}

Tabel 3. Perbandingan Tempat-tempat komuna berdasarkan asta kosala-kosali

\begin{tabular}{|c|c|c|c|}
\hline No. & $\begin{array}{c}\text { Nama Tempat Komunal } \\
\text { Menurut Asta Kosala- } \\
\text { kosali }\end{array}$ & $\begin{array}{l}\text { Nama Tempat Komunal } \\
\text { di Desa Balinuraga }\end{array}$ & Strategi Adaptasi \\
\hline & Tingkat $1 \mathrm{KK}$ & Tingkat 1 KK & \\
\hline 1. & Natah/Pekarangan & Natah/Pekarangan & $\begin{array}{l}\text { Pekarangan digunakan sebagai tempat berkumpul ketika } \\
\text { tuan rumah mengadakan acara dengan mengundang } \\
\text { masyarakat dan biasanya didirikan tenda temporer. }\end{array}$ \\
\hline 2. & Bale Sakepat & Bale Sakepat & $\begin{array}{l}\text { Bale ini masih digunakan untuk berkumpul keluarga } \\
\text { kecil, namun tidak semua rumah memiliki bale ini. }\end{array}$ \\
\hline & Tingkat 1 Pemaksan & Tingkat 1 Pemaksan & \\
\hline 3. & Natah/Pekarangan & Natah/Pekarangan & $\begin{array}{l}\text { Pekarangan tingkat pemaksan juga digunakan ketika } \\
\text { digelar upacara keluarga dengan menggunakan tenda } \\
\text { temporer pada halaman rumah. }\end{array}$ \\
\hline 4. & Bale Sakepat & Bale Sakepat & $\begin{array}{l}\text { Bale ini tidak terlalu difungsikan dengan baik karena } \\
\text { letaknya yang kurang strategis (dekat dengan tempat } \\
\text { ibadah dan sedikit tersembunyi) dan dengan alas an } \\
\text { lebih populernya bale dengan ukuran lebih besar. }\end{array}$ \\
\hline 5. & Bale Bengong & Bale Bengong & $\begin{array}{l}\text { Bale ini difungsikan tidak hanya untuk duduk bersantai } \\
\text { namun juga untuk para warga membuat kerajinan. }\end{array}$ \\
\hline 6. & Bale Kulkul & Bale Kulkul & $\begin{array}{l}\text { Bale ini masih difungsikan dengan baik untuk } \\
\text { memanggil warga berkumpul. }\end{array}$ \\
\hline 7. & Bale Banjar/Wantilan & Bale Banjar & $\begin{array}{l}\text { Bale ini difungsikan mulai bermusyawarah sampai } \\
\text { kegiatan seni karena sudah dilengkapi dengan panggung } \\
\text { untuk tampil. }\end{array}$ \\
\hline & Tingkat 1 Banjar & Tingkat 1 Banjar & \\
\hline 8. & Natah/Pekarangan & & $\begin{array}{l}\text { Bale banjar tingkat banjar/dusun memiliki pekarangan } \\
\text { yang luas sehingga dapat difungsikan juga sebagai } \\
\text { tempat berkumpul warga ketika sedang dilaksanakannya } \\
\text { acara yang cukup besar. }\end{array}$ \\
\hline 9. & Bale Kulkul & Bale Kulkul & $\begin{array}{l}\text { Bale ini masih difungsikan dengan baik untuk } \\
\text { memanggil warga berkumpul. }\end{array}$ \\
\hline 10. & Bale Banjar/Wantilan & Bale Banjar & $\begin{array}{l}\text { Bale ini difungsikan mulai bermusyawarah sampai } \\
\text { kegiatan seni karena sudah dilengkapi dengan panggung } \\
\text { untuk tampil. }\end{array}$ \\
\hline & Tingkat 1 Desa & ingkat 1 Desa & \\
\hline $\begin{array}{ll}11 . \\
12 .\end{array}$ & $\begin{array}{c}\text { Bale Kulkul } \\
\text { Bale Banjar/Wantilan }\end{array}$ & $\begin{array}{c}\text { Bale Kulkul } \\
\text { Bale Banjar/Wantilan }\end{array}$ & $\begin{array}{l}\text { Tidak ada. } \\
\text { Tidak ada. }\end{array}$ \\
\hline
\end{tabular}

6. Faktor-faktor yang Mempengaruhi Strategi Adaptasi Menurut Struktur Fungsionalisme

\section{Ekonomi}

Pada awal mula kedatangan transmigran dari pulau Nusa Penida, para transmigran membuka hutan dan bercocok tanam pada lahan yang disediakan pemerintah. Sekarang sebagian besar penduduk masih memiliki ladang sebagai salah satu sumber penghasilan mereka, namun di luar itu mereka memiliki pekerjaan utama seperti guru dan pedagang. Adanya kasta pada sistem struktur masyarakat tidak menghalangi 
untuk mendapatkan profesi dan kedudukan yang baik bagi kasta terendah sekalipun, sehingga tingkat kemampuan ekonomi cukup merata.

\section{Ekologi}

Kondisi alam atau geografi yang terdapat di Kalianda, Lampung Selatan sangat berbeda dengan apa yang terdapat di Nusa Penida. Pada asta kosala-kosali, terdapat pembagian tingkatan secara vertikal, yaitu Kaja (gunung), Madya dan Kelod (laut) yang menyebabkan keberadaan gunung pada tanah masyarakat suku Bali merupakan komponen penting. Di pulau Nusa Penida sendiri terdapat gunung tertinggi bernama gunung Mundi yang berarti poros. Sedangkan di Kabupaten Kalianda sendiri terdapat gunung Rajabasa, namun keberadaan dari gunung tersebut tidak dijadikan sebagai orientasi oleh masyarakat suku Bali etnis Nusa Penida yang bertempat tinggal di Kalianda tersebut.

\section{Politik}

Seiring berjalannya waktu, sedikit banyak sistem struktur pada masyarakat di desa Balinuraga berubah. Peran organisasi masyarakat dipegang oleh kasta Ksatria, namun belum tentu keturunan dari kasta Ksatria ini turut mengisi kursi-kursi sistem struktur kemasyarakatan pada masyarakat desa Balinuraga.

\section{Kebudayaan dan Pengetahuan}

Masyarakat terutama pada tokoh dan seniman yang bertugas sebagai arsitek memiliki peran penting dalam perkembangan permukiman dewasa ini telah memiliki pengetahuan yang baru dalam mengembangkan kualitas permukiman mereka diimbangi dengan inovasi baru sebagai bukti dari pengetahuan baru yang telah mereka pelajari. Kemajuan teknologi menyebabkan perubahan secara tidak langsung di mana masyarakat sekarang lebih menyukai proses yang efektif dan efisien. Seperti hiasan ukiran yang sekarang telah dengan mudah dapat dicetak walaupun untuk bangunan-bangunan tertentu masih menggunakan teknik ukir konvensional. Begitu juga dengan sistem konstruksi yang digunakan pada bangunan-bangunan yang ada, tidak lagi hanya mengandalkan konstruksi kayu, tapi juga mengutamakan konstruksi bata dan semen sesuai dengan kemampuan si pemilik bangunan.

\section{Sosialisasi}

Perubahan yang terjadi pada kependudukan seperti jumlah penduduk yang berubah, penyebaran serta kerapatan penduduk yang terus berubah secara dinamis mengingat cukup tingginya angka kelahiran. Hal ini menyebabkan desa terbagi menjadi 7 dusun di mana 5 di antaranya terdiri dari mayoritas suku Bali dan 2 dusun lainnya mayoritas terdiri dari penduduk transmigran dari pulau Jawa. Hal ini menyebabkan ketiadaan tempat komunal yang setara pada tiap dusun.

\section{KESIMPULAN}

Masyarakat suku Bali sudah lama datang sebagai transmigran di tanah serambi Sumatra. Suku Bali etnis Nusa Penida sendiri yang dulunya menjadi masyarakat buangan di pulau Nusa Penida sebagian memilih untuk merantau ke tanah yang lebih subur. Masyarakat suku Bali di Kalianda memulai dengan bercocok tanam membuka lahan yang lama-kelamaan banyak dari mereka memiliki profesi di luar desa selain berladang. Kondisi ekonomi masyarakat suku Bali di desa Balinuraga ini sangat baik sehingga memungkinkan mereka untuk memiliki rumahrumah ibadah dan tempat-tempat komunal dalam tingkat satu keluarga maupun satu marga dengan kondisi yang cukup baik.

Dari segi adat dan kebudayaan, mereka masih memegang teguh asta kosala-kosali yang terlihat dari penataan kampungnya, arah orientasi, rumah ibadah, serta tempat-tempat komunal yang tersedia. Namun, tetap ada sedikit perubahan dikarenakan kondisi alam, sosial dan ekonomi yang juga berbeda dengan yang terdapat di Nusa Penida sendiri. Faktor-faktor yang mempengaruhi adalah kondisi geografi yang berbeda, pengetahuan yang dimiliki masyarakat, sistem struktur sosial yang berubah, perubahan kependudukan, profesi yang dijalani oleh masyarakat dan sistem konstruksi bangunan-bangunan yang ada sekarang.

Faktor-faktor tersebut mempengaruhi pola tatanan permukiman di desa Balinuraga terutama pada tempat-tempat komunal di mana keberadaan tempat-tempat komunal pada tingkat keluarga dan tingkat keluarga satu marga menjadi kondisional serta tidak ditemukannya ruang komunal tingkat satu desa yang dapat digunakan sebagai sarana berkumpul masyarakat antar banjar. 
Keberadaan tempat-tempat komunal terutama pada permukiman suku pendatang yang memiliki kebudayaan dan kebiasaan hidup berbeda sangatlah penting sebagai salah satu sarana berkomunikasi dan saling mengenal satu sama lain demi menghindari kesalahpahaman dan menambah wawasan. Saran penulis dari aspek keilmuan arsitektur pada ranah sosial dan ekonomi adalah penyediaan tempat-tempat komunal pada tingkat satu desa sehingga memudahkan komunikasi masyarakat antar banjar mengingat 2 dusun dari 7 dusun bukan dihuni oleh mayoritas suku Bali serta dapat menjadi tempat untuk menyambut tamu-tamu dari luar desa Balinuraga dan dapat menyokong kualitas interaksi sosial dan menggali potensi ekonomi di desa Balinuraga ini.

\section{Daftar Pustaka}

Bagus, I. Gusti Ngurah, Drs., dkk. (1981) Latar Belakang Sosial Budaya Bahasa Bali Nusa Penida. Denpasar: Fakultas Sastra Universitas Udayana.

Dwijendra, Ngakan K. A. (2008) Arsitektur Rumah Tradisional Bali Berdasarkan Asta Kosala-kosali. Denpasar: Udayana University Press.

Gelebet, I Nyoman, Ir., dkk. (1985) Arsitektur Tradisional Daerah Bali. Denpasar: Departemen Pendidikan dan Kebudayaan Proyek Inventaris dan Dokumentasi Kebudayaan Daerah.

inputbali.com/budaya-bali/asta-kosala-kosalifengshui-tata-ruang-bangunan-bali

Kaplan, David, Manners, Albert (1999) Teori Budaya. Yogyakarta: Pustaka Pelajar.

Parsons, Talcott, in Truner, J. H. (1974) The Structure of Sociology Theory. Illnois: The Dorsey Press.

Parsons, Talcott (1961) The Social Theories of Talcott Parsons. United States: Prentice-Hall, Inc. Englewood Cliffs, N. J.

Pelly, Usman (1998) Urbanisasi dan Adaptasi. Jakarta: LP3ES.
Sanderson, S. K. (2003) Makro Sosiologi. Jakarta: PT Raja Grafindo Persada.

Soebandi, Ketut (1990) Konsep Bangunan Tradisional Bali. Denpasar: Percetakan Bali Post.

Utama, I Wayan Budi (2011) Adaptasi Budaya Masyarakat Bali Aga di Desa Cempaga Kabupaten Buleleng dalam Merespons Regulasi Negara di Bidang Agama. Denpasar: Universitas Udayana.

\section{DAFTAR INFORMAN}

Wayan Bagus; usia 32; pekerjaan guru; penduduk desa Balinuraga.

Wayan Parna; usia 56; pekerjaan guru; penduduk desa Balinuraga.

Wayan Gusti; usia 36; pekerjaan seniman; penduduk desa Balinuraga. 